\begin{tabular}{|c|c|c|c|c|c|c|}
\hline \multirow{4}{*}{ Impact Factor: } & ISRA (India) & $=4.971$ & SIS (USA) & $=0.912$ & ICV (Poland) & $=6.630$ \\
\hline & ISI (Dubai, UAE & $=0.829$ & РИНЦ (Russia & $=0.126$ & PIF (India) & $=1.940$ \\
\hline & GIF (Australia) & $=0.564$ & ESJI (KZ) & $=8.716$ & IBI (India) & $=4.260$ \\
\hline & JIF & $=1.500$ & SJIF (Morocco & $=5.667$ & OAJI (USA) & $=0.350$ \\
\hline
\end{tabular}

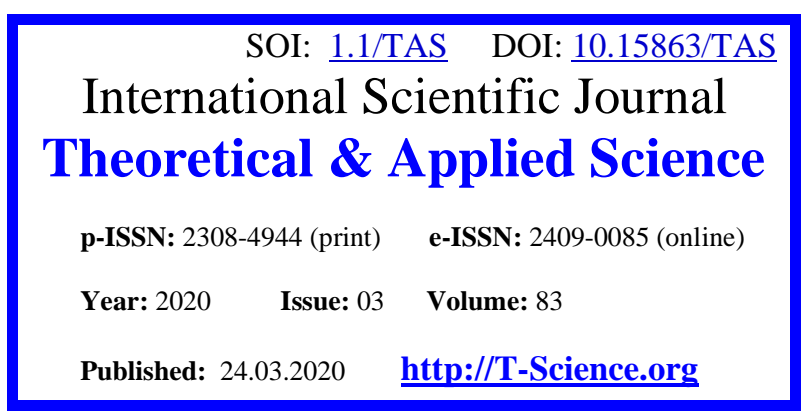

QR - Issue

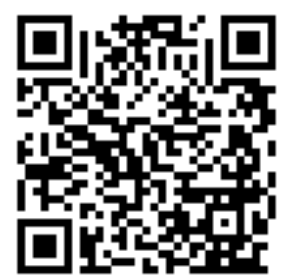

QR - Article

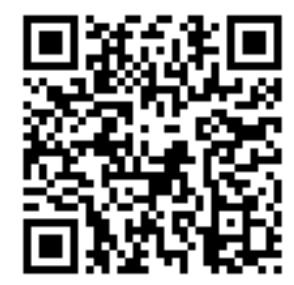

Denis Chemezov

Vladimir Industrial College M.Sc.Eng., Corresponding Member of International Academy of Theoretical and Applied Sciences, Lecturer, Russian Federation https://orcid.org/0000-0002-2747-552X chemezov-da@yandex.ru

Emil Akhmetov Vladimir Industrial College Student, Russian Federation

Vasiliy Semenov School №23 Teacher of chemistry, Vladimir, Russian Federation

Ilya Filippov Vladimir Industrial College Student, Russian Federation

Alexandr Petrenko Vladimir Industrial College Master of Industrial Training, Russian Federation

Alexey Kuznetsov Vladimir Industrial College Student, Russian Federation

Vladimir Serov Vladimir Industrial College Student, Russian Federation

Andrey Gradnikov Vladimir Industrial College Student, Russian Federation

\title{
DESTRUCTION OF THE BILLET MATERIAL DURING PLANING
}

Abstract: The cutting process of the steel billet with the planing cutter was simulated in the article. Nature of material destruction was described for the specified geometric parameters of the cutting tool. The values of the strain coefficients during destruction of the billet material were determined.

Key words: the model, the cutter, strain, material, destruction.

Language: English

Citation: Chemezov, D., et al. (2020). Destruction of the billet material during planing. ISJ Theoretical \& Applied Science, 03 (83), 34-38.

Soi: http://s-o-1.org/1.1/TAS-03-83-9 Doi: crossef https://dx.doi.org/10.15863/TAS.2020.03.83.9

Scopus ASCC: 2210. 


\begin{tabular}{|c|c|c|c|c|c|c|}
\hline \multirow{4}{*}{ Impact Factor: } & ISRA (India) & $=4.971$ & SIS (USA) & $=0.912$ & ICV (Poland) & $=6.630$ \\
\hline & ISI (Dubai, UAE & $=0.829$ & РИНЦ (Russia & $=0.126$ & PIF (India) & $=1.940$ \\
\hline & GIF (Australia) & $=0.564$ & ESJI (KZ) & $=8.716$ & IBI (India) & $=4.260$ \\
\hline & JIF & $=1.500$ & SJIF (Morocce & $=5.667$ & OAJI (USA) & $=0.350$ \\
\hline
\end{tabular}

\section{Introduction}

Planing is the process of machining the flat and shaped surfaces on the billet using the special cutting tool. The cutters are used as the cutting tools. The cutting part of the planing cutter is made in the form of the triangle for reducing cutting forces that occur during machining. The tool movement is straight. The planing process was researched in the works [1-10].

So as the cutting tool moves with high velocity during planing (compared to movement of the cutter during turning) then insignificant temperature loads will be distributed only in the deformed volume of the billet material. Destruction of the material layers during planing leads to strain on the resulting surfaces of the billet. Strain intensity of the processed material can be determined by calculating the values of the strain coefficients. Let us consider nature of strain of the metal billet during planing with the cutter with the positive rake angle.

\section{Materials and methods}

The cutting process with the planing cutter was simulated in the modules of the Ansys program. The three-dimensional statement of the researched problem is presented in the Fig. 1. The conditions for modeling the planing process of the billet in the Autodyn module are presented in the table 1 . The mechanical properties and the destruction parameters were set for material of the billet.
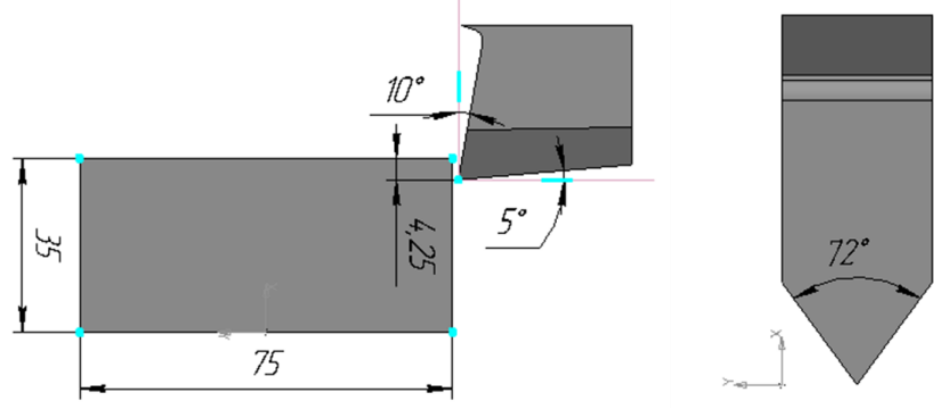

Figure 1 - The problem statement of machining the billet with the blade tool.

Table 1. The conditions for modeling the planing process.

\begin{tabular}{|l|l|}
\hline Materials & Rigid \\
\hline Cutter & Structural steel \\
\hline Billet & $7.85 \mathrm{~g} / \mathrm{cm}^{3}$ \\
\hline Reference density & Linear \\
\hline EOS & $1.666667 \times 10^{8} \mathrm{kPa}$ \\
\hline Model & $295.149994 \mathrm{~K}$ \\
\hline Bulk modulus & $434 \mathrm{~J} / \mathrm{kg} \times \mathrm{K}$ \\
\hline Reference temperature & \\
\hline Specific heat & von Mises \\
\hline Strength & $8.1 \times 10^{7} \mathrm{kPa}$ \\
\hline Model & $7.5 \times 10^{5} \mathrm{kPa}$ \\
\hline Shear modulus & \multicolumn{2}{|l|}{} \\
\hline Yield stress & Plastic strain \\
\hline Failure & $1.01 \times 10^{20}$ \\
\hline Model & Yes \\
\hline Plastic strain & 16 \\
\hline Stochastic failure & 0.1 \\
\hline Stochastic variance (gamma) & Fixed seed \\
\hline Minimum fail fraction & Geometric strain \\
\hline Distribution type & 1.5 \\
\hline Erosion & Instantaneous \\
\hline Model & 0.1 \\
\hline Erosion strain & \\
\hline Type of geometric strain & \\
\hline Cutoffs & \multicolumn{2}{|l|}{} \\
\hline Maximum expansion & \\
\hline
\end{tabular}




\begin{tabular}{|c|c|c|c|c|c|c|}
\hline \multirow{4}{*}{ Impact Factor: } & ISRA (India) & $=4.971$ & SIS (USA) & $=0.912$ & ICV (Poland) & $=6.630$ \\
\hline & ISI (Dubai, UAE & $=0.829$ & РИНЦ (Russia & $=0.126$ & PIF (India) & $=1.940$ \\
\hline & GIF (Australia) & $=0.564$ & ESJI (KZ) & $=8.716$ & IBI (India) & $=4.260$ \\
\hline & JIF & $=1.500$ & SJIF (Morocce & $=5.667$ & OAJI (USA) & $=0.350$ \\
\hline
\end{tabular}

\begin{tabular}{|c|c|}
\hline Minimum density factor & $1.0 \times 10^{-4}$ \\
\hline Minimum density factor (SPH) & 0.2 \\
\hline Maximum density factor (SPH) & 3 \\
\hline Minimum velocity & $1.0 \times 10^{-6}$ \\
\hline Maximum velocity & $1.0 \times 10^{10}$ \\
\hline Radius cutoff & 0.001 \\
\hline Strain rate cutoff & $1 \times 10^{-10}$ \\
\hline \multicolumn{2}{|l|}{ Solver } \\
\hline Hex integration & Exact \\
\hline Hex hourglass control & AD standard \\
\hline Viscous coefficient & 0.1 \\
\hline Tet integration & ANP \\
\hline Method for Lagrange/ALE density update & Automatic \\
\hline Method for Euler strain rate calculation & Weighted \\
\hline Method for Euler pressure calculation & Averaged \\
\hline \multicolumn{2}{|l|}{ Join } \\
\hline Join tolerance & 0.05 \\
\hline \multicolumn{2}{|l|}{ Interactions (Lagrange/Lagrange) } \\
\hline Type & Trajectory \\
\hline Method & Penalty \\
\hline \multicolumn{2}{|l|}{ Timestep options } \\
\hline Safety factor & 0.9 \\
\hline Method of calculating characteristic zone dimension & Diagonals \\
\hline \multicolumn{2}{|l|}{ Damping options } \\
\hline Quadratic viscosity & 1 \\
\hline Linear viscosity & 0.2 \\
\hline Hourglass damping & 0.1 \\
\hline \multicolumn{2}{|l|}{ Transport } \\
\hline Material velocity timestep safety factor & 1 \\
\hline Euler-FCT & Multidimensional \\
\hline ALE/Euler energy & Total \\
\hline Euler & SLIC \\
\hline
\end{tabular}

The solid models of the cutting tool and the billet were divided into the finite elements. The minimum length of the element edge was $1.5437 \times 10^{-2} \mathrm{~m}$. The total number of the elements was 111362 . Refinement that reduced the size of the finite elements in removed allowance was performed on the processed surface of the billet model. The billet model was fixed by the side surfaces and the unprocessed flat surface. The cutter model was moved to the billet model with constant velocity. Splitting the three-dimensional models into the finite elements, setting velocity of the cutter and fixing the billet are presented in the Fig. 2 .

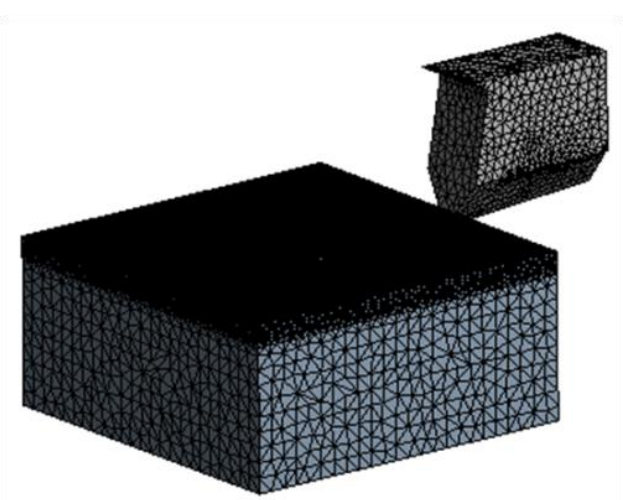

A

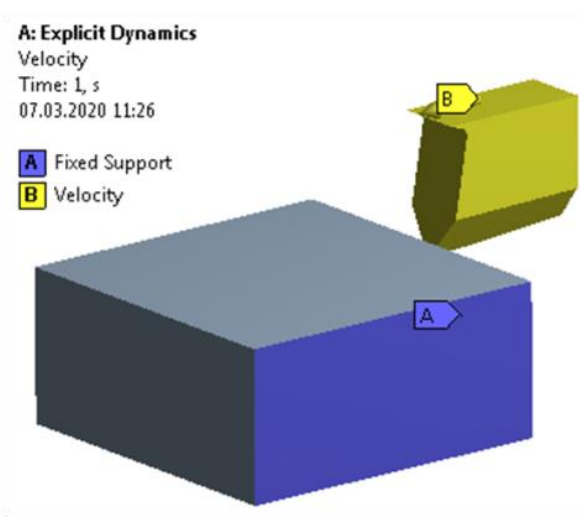

$B$

Figure 2 - The conditions for modeling the planing process: $A$-splitting the billet and cutter models into the finite elements, $B$ - setting velocity of the cutter and fixing the billet. 


\begin{tabular}{|c|c|c|c|c|c|c|}
\hline \multirow{4}{*}{ Impact Factor: } & ISRA (India) & $=4.971$ & SIS (USA) & $=0.912$ & ICV (Poland) & $=6.630$ \\
\hline & ISI (Dubai, UAE & $=0.829$ & РИНЦ (Russia & $=0.126$ & PIF (India) & $=1.940$ \\
\hline & GIF (Australia) & $=0.564$ & ESJI (KZ) & $=8.716$ & IBI (India) & $=4.260$ \\
\hline & JIF & $=1.500$ & SJIF (Morocce & $=5.667$ & OAJI (USA) & $=0.350$ \\
\hline
\end{tabular}

\section{Results and discussion}

The cutting process with the planing cutter is presented in the Fig. 3. The cutting part of the planing cutter was moved along the processed surface of the billet by $15 \mathrm{~mm}$. Chips are formed on the front surface of the cutter during the chipping layers of the billet material. It is known that material in the cutting zone is subjected to maximum strain. The strain degree of the billet material during cutting can be characterized by the values of the strain coefficients. The simulation results are presented by the strains contours of the billet material during planing (the Figs. 4-5).

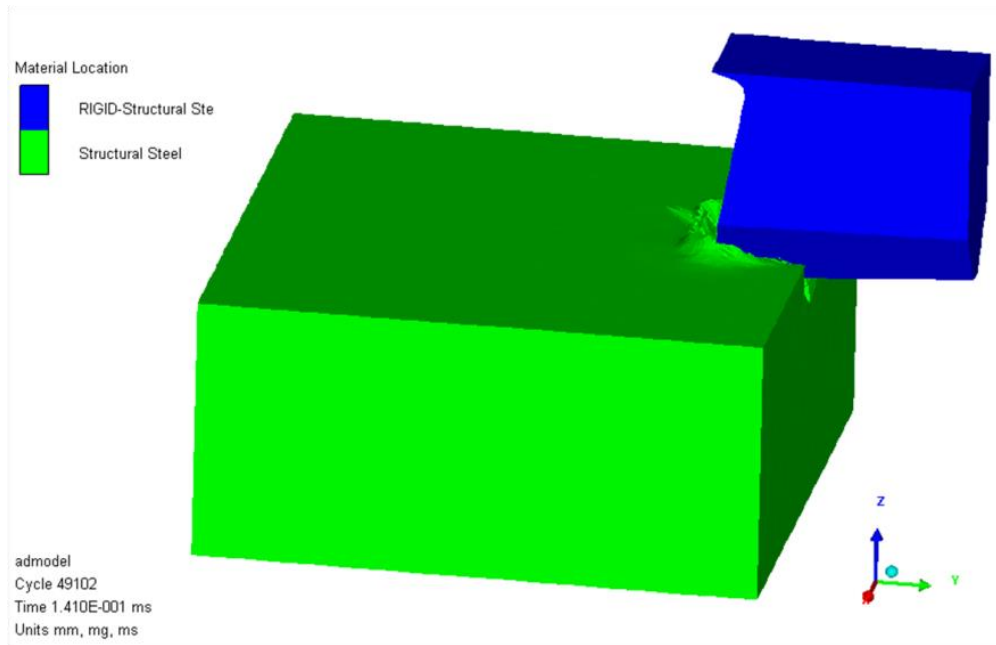

Figure 3 - The cutting process with the planing cutter.
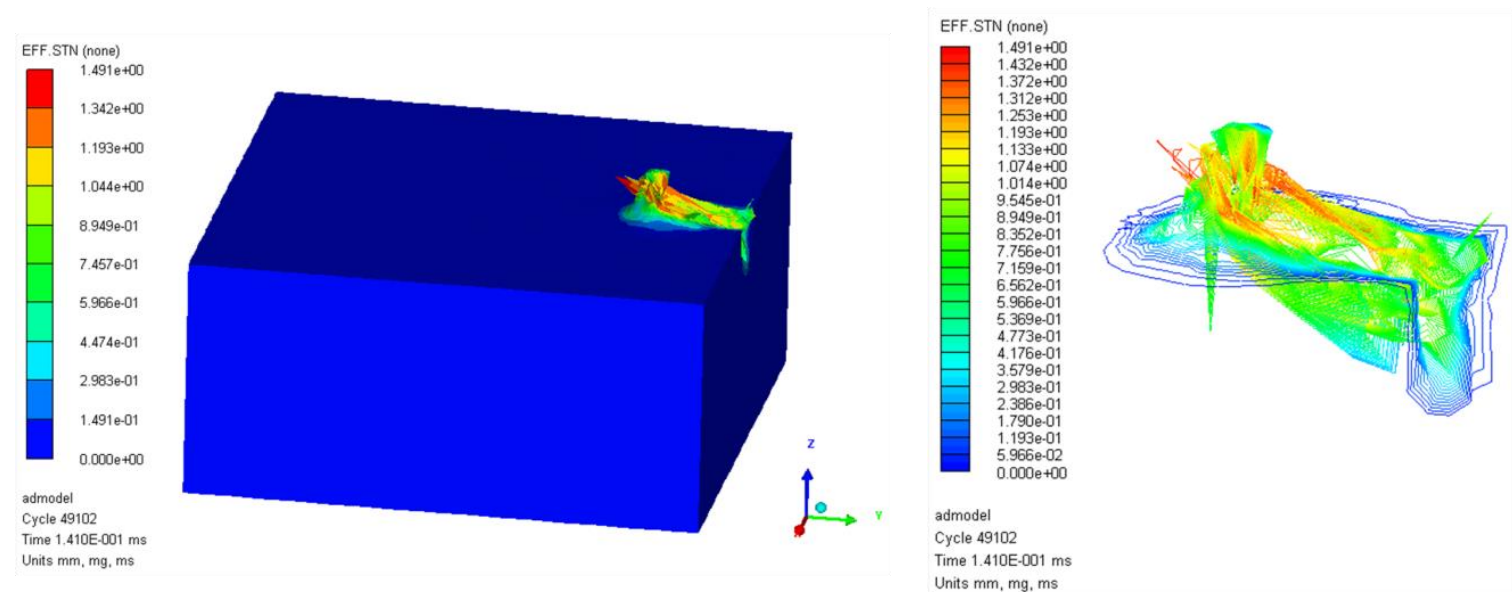

Figure 4 - The contours of effective strain of the billet material during planing.
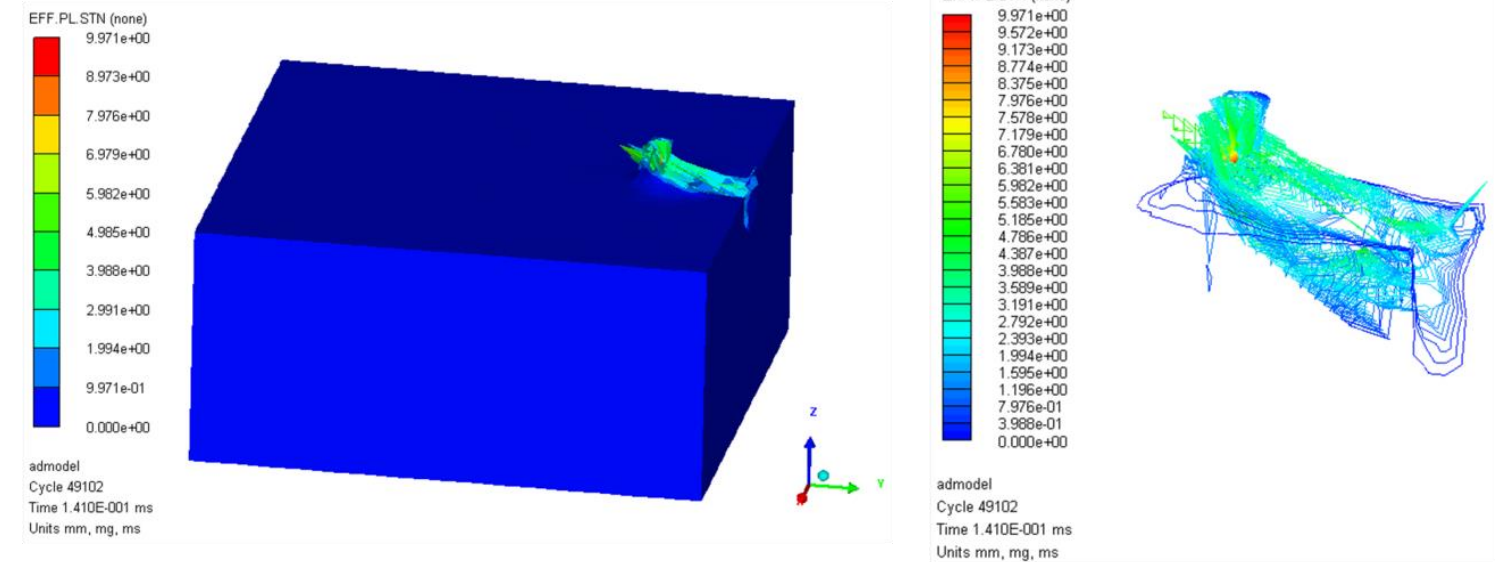

Figure 5 - The contours of effective plastic strain of the billet material during planing. 


\begin{tabular}{|c|c|c|c|c|c|c|}
\hline \multirow{4}{*}{ Impact Factor: } & ISRA (India) & $=4.971$ & SIS (USA) & $=0.912$ & ICV (Poland) & $=6.630$ \\
\hline & ISI (Dubai, UAE & $=0.829$ & РИНЦ (Russia & $=0.126$ & PIF (India) & $=1.940$ \\
\hline & GIF (Australia) & $=0.564$ & ESJI (KZ) & $=8.716$ & IBI (India) & $=4.260$ \\
\hline & JIF & $=1.500$ & SJIF (Morocce & $=5.667$ & OAJI (USA) & $=0.350$ \\
\hline
\end{tabular}

The contours of effective strain give an idea of the volume of deformed (destroyed) material of the billet. Strain accumulates during the entire process. Metal is destroyed in the cutting zone at the coefficient of effective strain of 1.1 (with the small positive rake angle of the cutter). The processed side surfaces of the billet after moving the cutting tool are deformed 1.55 times less than material in the cutting zone. So as the cutting process is carried out during the stationary billet then the main factor of maximum strain will be the largest contact area of the front surface of the planing cutter with material.

The contours color of the coefficient of effective plastic strain indicates uniform destruction of the billet material in all layers of removed allowance. Exception is the volume of material that is deformed at the nose of the cutter. On average, the value of the coefficient of effective plastic strain varies in the range of 1.2...3.5. The coefficient of effective plastic strain of the billet material can reach 10 in the zone of active destruction.

\section{Conclusion}

Thus, based on the results of computer modeling, the following conclusions can be drawn:

1. Planing the billet with the proposed positive rake angle of the cutting tool does not lead to active chip formation.

2. Structural steel with the specified mechanical properties is destroyed at the coefficient of effective strain of 1.1. The billet surface in contact with the nose of the cutting tool is deformed at the coefficient of effective strain of 0.89 .

3. The coefficient of effective plastic strain during planing varies in the range of 1.2-10. The maximum value of the coefficient is observed in the zone of chip formation.

\section{References:}

1. Yakovtsev, A. D. (1966). Work on planing and slotting machines. (p.290). Moscow: Higher school.

2. Vereina, L. I. (2002). Treatment on the planing and slotting machines: The handbook. Technologist's library. Publisher: Mechanical Engineering, p.304.

3. Vorontsov, A. L., Sultan-Zade, N. M., \& Albagachiev, A. Yu. (2008). Development of a new cutting theory. 10. Planing and stretching. Russian Engineering Research, №10, 71-72.

4. Vorontsov, A. L. (2008). Development of modern theory of mechanical processing of metals. Part 8. Planing and broaching. Manufacture of hire, №8, 3-5.

5. Esterzon, M. A. (2007). The revival of planing. The Journal of Metalworking «Chip», №1, 3440.

6. Durov, D. S., \& Rybinskaya, T. A. (2008). Modeling of the process of planing the part.
Izvestiya SFedU. Engineering Sciences, 1 (78), 202-203.

7. Katunin, A. V. (2008). Decreasing of the vibrations by planing. Izvestia Orel State Technical University, 3-7 (271), 24-29.

8. Nikonov, A. A., \& Kameneva, A. L. (2016). Features of planing the grooves with the figurine tool in long pipes. Problems and prospects of mechanical engineering development, 177-183.

9. Smaylovskaya, M. S., \& Gatovskiy, M. B. (2011). Multipass planing with a controlled movement of the cutter. Rhythm: Repair. Innovations. Technologies. Modernization, 10 (68), 22-23.

10. Chemodanov, A. N., Boyarsky, M. V., Gainullin, Ren. Kh., \& Gainullin, Rish. Kh. (2011). To the question on accuracy of woodcutting force definition at longitudinal planing. Bulletin of the Mari State Technical University. Series: Forest. Ecology. Nature management, №2, 61-67. 